\title{
Should I or Should I Not? The Effects of Prostaglandin E2 on Mate-Search behavior, in Female Crickets, Acheta Domesticus
}

\author{
Article by Tsukasa Jonathan Tanaka, M.S. ${ }^{1 \& 2}$ \\ ${ }^{1}$ Texila American University, Guyana \& Universidad Central de Nicaragua \\ ${ }^{2}$ California State University, Fullerton. Fullerton, CA, USA \\ E-mail: tjtanaka@gmail.com ${ }^{2}$
}

\begin{abstract}
Sexual conflict occurs when the costs and benefits of mating differ between males and females. Numerous studies have confirmed that compounds in the seminal fluids of males can impact females. These impacts include manipulation of egg laying, reductions in innate immune responses, and altering behavior. Prostaglandin E2 (PGE2) is a compound found in the spermatophore of house crickets and initiates oviposition behavior in female crickets. Here, I speculate that PGE2 may affect mate-search behavior in house crickets in a dose-dependent manner. Past studies have indicated PGE2 also simulate multiple mating by giving female house crickets multiple injections of PGE2. This experiment investigated the phonotactic (latency to reach an acoustic stimulus) response of females when injected with PGE2. The female crickets were raised until adult eclosion and the phonotactic cues were measured $24 \mathrm{~h}$ after injection with a $1 \mu \mathrm{g}, 10 \mu \mathrm{g}, 100 \mu \mathrm{g}$ dose of PGE2 dissolved in $1 \mu \mathrm{L}$ EtOH and $9 \mu \mathrm{L}$ of phosphate buffer saline (PBS). Controls were injected with $1 \mu \mathrm{LEtOH}$ and $9 \mu \mathrm{L} p f$ PBS only. Crickets were randomly assigned $(n=10)$ to each group prior. Acoustic stimuli were applied afterwards. The latency to respond to male signals was not impacted by PGE2; thus, PGE2 does not impact other aspects of female behavior or life-history that can be manipulated by other components of male seminal fluids.
\end{abstract}

\section{Introduction and conceptual background}

Mate selection can create an asymmetry in evolutionary interests, since two persons rarely have exactly the same allelic and genomic composition (reviewed in Arnqivist and Rowe, 2005). These differences are similar to parental and child interest asymmetry (Trivers 1972). Thus, the strategy and behavior of matt selection will differ between women and men depending on the amount of investment that individual devotees towards future children (Parker, 1979). This asymmetry can generate a more expensive and larger sex cell (gametes) before conception, while males tend to produce a less expensive and smaller sex cell (sperm) (Bateman 1948). Therefore, a conflict for the pursuit of individual, evolutionary interests can arise through reproductive strategies and sexual selection that can lead to gender divergence (Parker, 1979). The theory of sexual conflict explains how differences in the interests of men and women generate coevolution between men and women (reviewed in Chapman et al., 2003).

Genetically speaking, sexual conflict can also be investigated. The difference in morphology, physiology and behavior is based on the genetic differences between the sexes. Genetic sexual conflict may be both intralocal and interlocutory (Parker and Partridge, 1998). That is, according to the sex, there are different selective pressures at the same location. The other genetic instance of sexual conflict is the sexual conflict. This happens when two alleles interact with one sex and have a negative effect on the other sex (reviewed in Arnqvist and Rowe, 2005). Interlocus sexual conflict results in a " arms race " scenario in which sexual antagonism can be observed. (Price and Burley, 1994). The other instance of sexual conflict at the genetic level is interlocus sexual conflict. This occurs when, at two loci, two alleles interact resulting in a trait in one sex that has a negative impact on the other sex (reviewed in Arnqvist and Rowe, 2005). Interlocus sexual conflict results in an "arms race" scenario where antagonistic co-evolution of the sexes can be observed. Sexual conflict can occur in many forms, including pre-copulatory behavior and mating-related phenotypes, parental care, fertilization tactics and even post-mating (Parker and Partridge, 1998). The most convincing examples of sexual 
conflict occur when males use chemicals in their ejaculates to manipulate females ' behavior in a manner that benefits the male but costs the female (Arnqvist and Rowe, 2005).

The chemical manipulation of female invertebrates is investigated in many studies. For example, in Drosophila melanogaster, male ejaculates contain oviposition-initiating compounds such as ovulin (Chapman et al., 2003). In female Drosophila melanogaster, longevity in matted versus unmated females is also greatly reduced (Chapman et al., 1995). Female crickets, Gryllus bimaculatus, injected with seminal male fluid showed a reduction in lifespan, although the oviposition rate was not different from controls (Green and Tregenza, 2009). Many have assumed that such compounds could affect the integrity, ageing and stress of the immune systems (Stanley et al., 2009). Similar compounds can interestingly be found in male house crickets (Destephano et al., 1974). Prostaglandin E2 (PGE2), an eicosanoid subclass, initiates female house cricket oviposition (Loher, 1979; Destephano et al., 1974). Some prostanoids also change the invertebrates ' immune response (Stanley et al., 2009).

Eicosanoids are oxygenated 20-Carbon (C20) polyunsaturated fatty acid metabolites. They have received a lot of attention due to their role in a number of signaling pathways in a large number of organisms. Prostaglandins (a subclass of eicosanoids) act on cells and systems where they are synthesized, unlike other endocrine hormones; therefore, they are more considered autocrine hormones, can act on a wide variety of cell types and function differently (Norman and Litwack, 1989). In mammalian models, most notably prostaglandins play a role in oxidative stress, neuronal toxicity, innate immune activation and several other key regulators (Ford-Hutchinson, 1994; McGiff, 1981; Milatovic et al., 2011). In comparison with mammals, the literature documenting the role of prostaglandin in invertebrates is minimal. The first prostaglandin was isolated from the seminal vesicles of mammals (Bergstrom et al., 1962), but it was not until 1969 that the first invertebrates of prostaglandin, Plexaura homomall (Weinheimer and Spraggins, 1969), were discovered in the sea vault. Eicosanoids influence the behavior of reproduction in invertebrates. Most notably, PGE2 appears to initiate a female house cricket oviposition behavior (Destephano et al., 1974).

Individuals have only a limited amount of energy for reproductive purposes (Pianka 1976). Women can invest energy in offspring, innate immunity or other homeostatic maintenance mechanisms. The more energy females reproduce, the less energy they allocate to their immunity or other life functions. A trade-off of energy allocation to reproduction or immunity could therefore be observed. Empirical studies have found that women will allocate more resources for the future well - being of their offspring either as parental care or as nutritional output (such as antioxidants, increased egg sizes containing more nutrients, etc.) (reviewed in Ratikaninen and Kokko, 2009). A mate can reduce the oviposition frequency when faced with an immune challenge (Bascuñán-García and Córdoba-Aguilar, 2010). In addition, a previous study showed that matted women had a lower immune response than unmated women (Bascuñán-García and Córdoba-Aguilar, 2010). This is interesting because the compounds in the male ejaculate can influence both the immunological and ovipositional responses. It is evident from the above studies that the male ejaculate influences female longevity and immune response. The above study may indicate that priority is given to the energy allocation for egg production. The activation of immune cells by PGE2 can, however, be expensive for the ability of women to increase the oviposition rate. Mating increases longevity in Gryllus campestris (Wagner et al. 2001). It's a paradox. Oxidative stress and neural toxicity in mammals may be caused (Milatovic, 2011). In addition, many cricket species mates with more than one partner; therefore, there may be several reasons why the female and her offspring(s) can benefit from multiple mating (Fleischman and Sakaluk, 2004; Wagner et al., 2001). One example is the indirect benefits in the form of interactions of parental genomes to create genetic diversity (Zeh and Zeh, 2001). Direct benefits to the female (and its offspring) can be seen in the form of nuptial gifts that contribute to immediate and future fitness (Sakaluk el al., 2006; Simmons, 1986; Vahed, 1998). However, there seem to be two contradictory results in prior studies. First, female crickets do not show reduced receptivity after mating (Fleischman and Sakaluk, 2004). Second, mating reduces phonotactic behavior in females (Bateman, 2001). These are important to consider when quantifying post-mating behaviors because phonotactic response towards a male calling indicates the receptivity to invest time and energy for the females to find a mate that is calling from a distance. 
I will investigate the possible influence of PGE2 on the house cricket mate search behavior, Acheta domesticus. PGE2-dose females show reduced phonotactic response to male calling songs after PGE2, similar to a separate study showing reduced receptivity in females of a different species after matching (Bateman, 2001). Females can also show no change in phonotactic response to the hypothesis that there are no manipulators of receptivity in male ejaculates (Green and Tregenza, 2009; Fleischman and Sakaluk, 2004).

\section{Methods}

\section{overview}

Virgin female House Crickets (Acheta domesticus) were injected with varying concentrations of PGE2 dissolved in $1 \mu \mathrm{L} \mathrm{EtOH}$ and $9 \mu \mathrm{L}$ phosphate buffered saline (Insect Ringer's; PBS) solution $\left(\mathrm{NaCl} 128.4 \mathrm{mM} \mathrm{g}, \mathrm{KCl} 4.7 \mathrm{mM}, \mathrm{CaCl}_{2} 1.9 \mathrm{mM}\right.$, and $\mathrm{NaH}_{2} \mathrm{PO}_{4}$ as buffers for adjusting pH levels) (Ephrussi and Beadle, 1936). Controls were injected with $1 \mu \mathrm{L} \mathrm{EtOH}$ and $9 \mu \mathrm{L}$ Insect Ringer's; PBS solution only. I applied an acoustic stimulus to determine the impact of exposure to PGE2 on female phonotactic behavior. Crystallized PGE2 was purchased from Cayman Chemicals. Different concentrations $(1 \mu \mathrm{g}, 10 \mu \mathrm{g}$, and $100 \mu \mathrm{g})$ of PGE2 were dissolved in $1 \mu \mathrm{L} \mathrm{EtOH}$ and $9 \mu \mathrm{L}$ phosphate buffer saline (Insect Ringer's; PBS) solution as indicated in Cayman Chemicals protocol (Cayman Chemicals, 2011). The females were anesthetized by inserting them in the freezer for 5-6 min. The females were randomly injected with the above solutions or a $1 \mu \mathrm{L} \mathrm{EtOH}$ and $9 \mu \mathrm{L}$ pf PBS only for controls at the third to fourth abdominal tergite.

\section{Insect maintenance}

Four-week-old Acheta domesticus were ordered from Fluker's Cricket Farm as noted elsewhere and housed in large plastic bins until 14 days after adult eclosion. Crickets had access to food (Purina cat chow) and water ad libitum. They were kept in a $28^{\circ} \mathrm{C}$ environment on a $12 \mathrm{hr}: 12 \mathrm{hr}$ light-dark cycle. Trial crickets were moved individually to a smaller, separate $14 \times 14 \times 13 \mathrm{~cm}$ plastic bin to avoid interactions with other crickets.

\section{Influence on female mate search behavior}

This experiment investigated the phonotactic (latency to reach an acoustic stimulus) response of females when injected with PGE2. The female crickets were raised until adult eclosion and the phonotactic cues were measured $24 \mathrm{~h}$ after injection with a $1 \mu \mathrm{g}, 10 \mu \mathrm{g}, 100 \mu \mathrm{g}$ dose of PGE2 dissolved in $1 \mu \mathrm{L} \mathrm{EtOH}$ and $9 \mu \mathrm{L}$ of PBS. Controls were injected with $1 \mu \mathrm{L} \mathrm{EtOH}$ and $9 \mu \mathrm{L}$ pf PBS only. I am employing a playback mating call of a large attractive male (e.g., Gray, 1997; Stoffer and Walker, 2012) at a setting of $57 \mathrm{~dB}$. Again, the female crickets were randomly placed in groups. Songs of attractive males that have been verified to attract females (Stoffer and Walker, 2012) were used. The crickets were allowed to acclimate to the speaker apparatus for 3 minutes. Phonotactic responses were measured by observing the latency to move onto the speaker broadcasting the song. Latencies were analyzed using survival analysis to compare the effect of different doses of PGE2 on mate-search behavior. The average temperature for all trials was $27.74^{\circ} \mathrm{C}+1.62$ with a maximum temperature of $31.30^{\circ} \mathrm{C}$ and a minimum temperature of $25^{\circ} \mathrm{C}$. The sample sizes are described in Table 1 and Appendix B.

\section{Statistical analysis}

All experiments were analyzed by single or two-factor Analysis of Covariance (ANCOVA) unless stated otherwise. I used ANCOVA to control for differences in female mass across treatments and to more precisely estimate treatment effects. Female mass was used as a covariate (Unpublished data). Multiple comparisons were done using Tukey's Honestly Significant Difference test (Tukey's HSD) (Unpublished data). In some cases data were $\log$ or $\log +1$ transformed to meet the assumptions of the analysis. Latencies to respond to songs were analyzed using survival analysis to compare the effect of different doses of PGE2 on mate-search behavior. All statistical analysis was done using $\mathrm{R}$ (http://www.r-project.org/). 
DOI: 10.21522/TIJAR.2014.SE.19.01.Art005

ISSN: $2520-3088$

Table 1. Data table to indicating controls used and dose in micrograms cohort. Acoustic stimuli indications are noted as Yes or No

\begin{tabular}{|l|l|l|}
\hline ID & Acoustic Stimuli & Sample Size (n) \\
\hline $\begin{array}{l}\text { Untreated } \\
\text { Control }\end{array}$ & No & 25 \\
\hline $\begin{array}{l}\text { Untreated } \\
\text { Control }\end{array}$ & Yes & 24 \\
\hline Sham Control & No & 25 \\
\hline Sham Control & Yes & 25 \\
\hline 100 ug & Yes & 23 \\
\hline 10 ug & Yes & 21 \\
\hline 1 ug & Yes & 14 \\
\hline
\end{tabular}

\section{Results}

\section{Latency to mating}

The latency to mounting speakers did not differ statistically when compared between the cohorts that received a sham injection (ISR+EtOH) versus those that were untreated (Figure 1). However, the cohorts that received an acoustic stimulus versus those that did not showed a significant decrease in the latency to mount the speaker (Figure 1). The application of PGE2 doses did not change latency to mount the speaker among the different treatment groups (Figure 1).

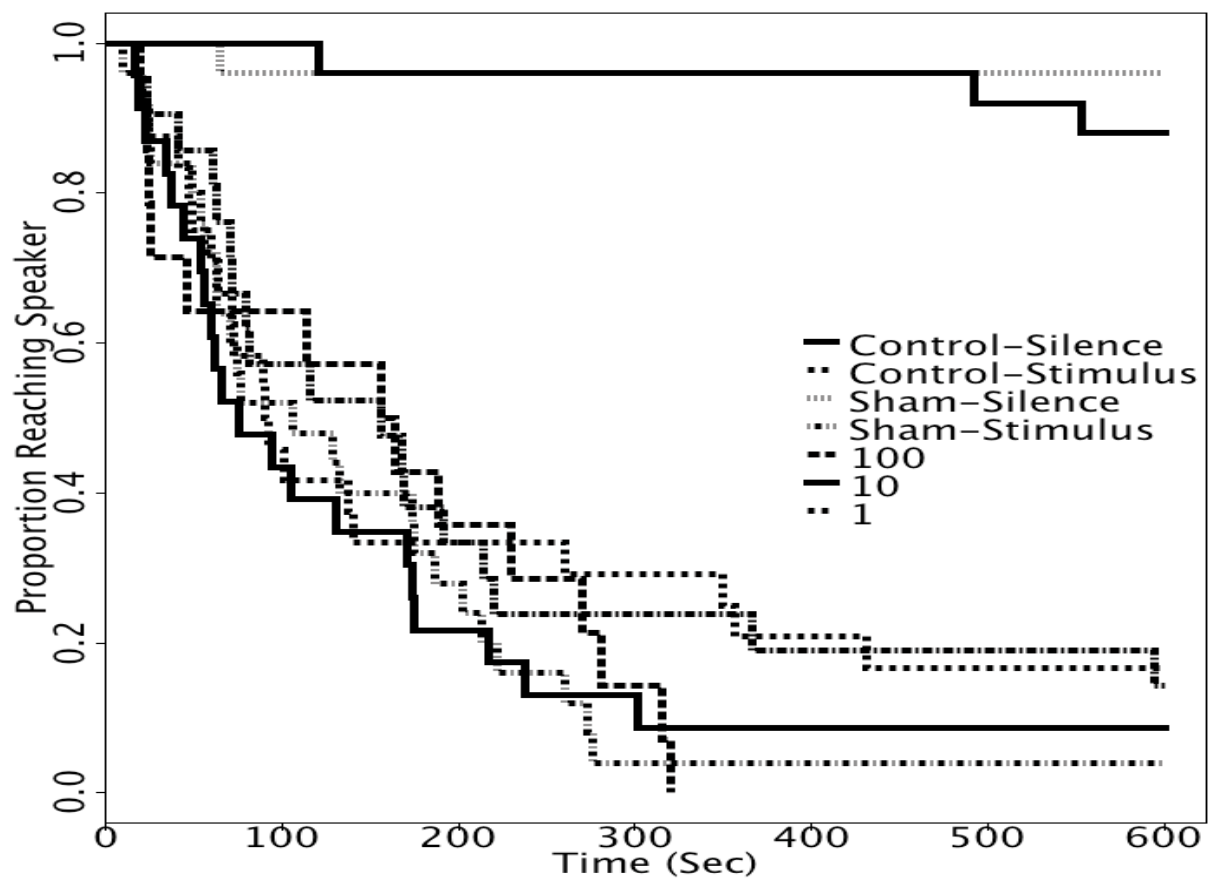

Figure 1.

Figure 1: The latency to mounting speakers did not differ statistically when compared between the cohorts that received an acoustic stimulus (Log-rank test: $\chi^{2}=2.99, \mathrm{DF}=4, \mathrm{P}=0.5594$ ). However, the cohorts that received an acoustic stimulus versus those that did not showed a significant effect on the latency to mount the speaker (Log-rank test: $\chi^{2}=90.6, \mathrm{DF}=1, \mathrm{P}<0.0001$ ).

\section{Discussion}

\section{Summary of results}


My data demonstrate that The latency to mount a speaker did not show any differences between groups that received PGE2 treatment. However, the application of the acoustic stimulus had a significant effect than those that did not (i.e. acoustic stimulus was required for the crickets to mount the speaker).

\section{Influence on female mate search behavior}

The injection of PGE2 did not impact the latency to mount when received an acoustic stimulus compared to controls or within treatment groups. However, an acoustic stimulus showed a mounting response to the speakers to those that didn't receive an acoustic stimulus and suggests that females responds well to acoustic stimulus from speakers, of which, is consistent with a prior study (Stoffer and Walker, 2013). The female's behavior in mounting the acoustically active speaker after injection of PGE2 is consistent with other laboratory and field observations where A. domesticus females can mate multiple times a day (e.g. Kindle et al., 2006). However, this does not provide an explanation to why the latency to mounting an acoustically active speaker did not statistically change or decrease within PGE2 groups or between sham and untreated controls. This is particularly interesting to note because the injection of PGE2 is energetically costly to females because it induces egg laying behavior as shown in my study and past studies (e.g. Loher, 1979; Destephano et al., 1974), decreases immune response as shown in my study, and could contribute to oxidative stress (e.g. FordHutchinson, 1994; McGiff; 1981; Milatovic et al., 2011). In addition, there are no direct benefits to female A. domesticus through mating, such as nuptial gifts (reviewed in Vahed, 2007). Therefore, females should show be hesitant to re-mating because there is no direct benefit to her and prostaglandins could potentially be harmful, yet we observed no effect in response. Perhaps this finding may suggest that females choose multiple mates to increase the probability of accumulating good genes (e.g. Simmons, 1987; Head et al., 2006), to avoid genetic incompatibilities and deleterious genes (e.g. Simmons et al., 2006), and/or the indirect benefit of attractive off springs (Fisher, 1930; Wedell and Tregenza, 1999). Therefore, the pros of investing in a more attractive and/or fit offspring negates any deleterious impact acquired from mating with more males.

\section{Conclusion}

Female house crickets are impacted from sexual conflict as demonstrated in my studies. First, males seem to manipulate the female reproductive system to prime and induce laying egg. Lastly, prostaglandins in male ejaculate do not influence mate search behavior after exposure. Although, my studies do not definitively demonstrate that antagonistic coevolution (interlocus sexual conflict) is occurring because of PGE2 in male ejaculates, my study imply that PGE2 from males has fitness consequences for females following mating. Perhaps, future studies could test for antagonistic coevolution and also examine the relationship between the quantity of fecundity stimulating substances in attractive and less attractive males.

\section{APPENDIX B}

\section{References}

[1]. Arnqvist G and Rowe L. 2005. Sexual Conflict. Princeton University Press, Princeton, NJ.

[2]. Bascuñán-García AP, Lara C, Córdoba-Aguilar A. 2010. Immune investment impairs growth, female reproduction and survival in the house cricket, Acheta domesticus. Journal of Insect Physiology 56:204-211.

[3]. Bateman A J. 1948. Intra-sexual selection in Drosophila. Heredity. 2(Pt. 3), 349-368.

[4]. Bergstrom S, Ryhage R, Samuelsson B. and Sjovall J.1962. The structure of prostaglandin E, F and F 2. Acta Chemica Scandinavica. 16:501-502.

[5]. Cayman Chemical Company. www.caymanchem.com, 2011.

[6]. Chapman T, Liddle LF, Kalb, JM, Wolfner MF and Partridge L.1995. Cost of mating in Drosophila melanogaster females is mediated by male accessory-gland products. Nature 373:241-244.

[7]. Chapman T, Bangham J, Vinti G, Seifried B, Lung O, Wolfner M, Smith H, and Patridge L. 2003. The sex peptide of Drosophila melanogaster: Female post-mating responses analyzed by using RNA interference. Proc Natl Acad Sci USA 100:9923-9928.

[8]. Chapman T, Arnqvist G, Bangham J, Rowe L. 2003. Sexual conflict. Trends in Ecology and Evolution 
$18: 41-47$

[9]. Chapman T, and Partridge L. 1996. Female fitness in Drosophila melanogaster: an interaction between the effect of nutrition and of encounter rate with males. Proceedings: Biological Sciences. 755-759.

[10]. Destephano DB, Brady UE, Farr CA. 1982. Factors Influencing Oviposition Behavior in the Cricket, Acheta domesticus. Annals of the Entomological Society of America 75:111-114.

[11]. Destephano DB and Brady UE. 1977. Prostaglandin and prostaglandin synthetase in the cricket, Acheta domesticus. Journal of Insect Physiology 23:905-911.

[12]. Destephano DB, Eugene Brady U, Woodall LB. 1976. Partial characterization of prostaglandin synthetase in the reproductive tract of the male house cricket, Acheta domesticus. Prostaglandins 11:261-273.

[13]. Destephano DB, Brady UE, Lovins RE.1974. Synthesis of prostaglandin by reproductive tissue of the male house cricket, Acheta domesticus. Prostaglandins 6:71-79.

[14]. Ephrussi B, and Beadle, GW. 1936. A technique of transplantation for Drosophila. American Naturalist. 218-225.

[15]. Fleischman RR, and Sakaluk SK. 2004. Sexual conflict over remating in house crickets: no evidence of an anti-aphrodisiac in males' ejaculates. Behaviour 141: 633-646.

[16]. Ford-Hutchinson AW. 1994. Regulation of leukotriene biosynthesis. Cancer Metastasis Rev. 13: 257-267.

[17]. Green K and Tregenza T, 2009. The influence of male ejaculates on female mate search behaviour, oviposition and longevity in crickets. Animal Behaviour 77:887-892.

[18]. Head M., Hunt J, and Brooks R. 2006. Genetic association between male attractiveness and female differential allocation. Biology letters. 2:3: 341-344.

[19]. Kindle TK, Johnson KM, Ivy TM, Weddle CB, and Sakaluk SK. 2006. Female mating frequency increases with temperature in two cricket species, Gryllodes sigillatus and Acheta domesticus (Orthoptera: Gryllidae). Canadian journal of zoology. 84:9: 1345-1350.

[20]. Loher W. 1979. The influence of Prostaglandin E2 on oviposition in Teleogryllus commodus. Entomologia Experimentalis et Applicata 25:107-109. doi: 10.1111/j.1570-7458.1979.tb02853.x.

[21]. Milatovic D, Montine TJ, Aschner M. 2011. Prostanoid signaling: Dual role for prostaglandin E2 in neurotoxicity. Neuro Toxicology 32:312-319.

[22]. Norman AW, and Litwack G. 1997. Hormones: Academic Press.

[23]. Parker G, and Blum M. 1979. Sexual selection and sexual conflict. Sexual selection and reproductive competition in insects. 123: 166.

[24]. Parker G, and Partridge L. 1998. Sexual conflict and speciation. Philosophical Transactions of the Royal Society of London. Series B: Biological Sciences. 353:1366: 261-274.

[25]. Pianka E. R 1976. Natural selection of optimal reproductive tactics. American Zoologist 16: 775-784.

[26]. Price DK, and Burley NT. 1994. Constraints on the evolution of attractive traits: selection in male and female zebra finches. Am. Nat. 144:908-934

[27]. R Development Core Team. 2011. R: A language and environment for statistical computing. R Foundation for Statistical Computing, Vienna, Austria. ISBN 3-900051-07-0, URL http://www.R-project.org/.

[28]. Ratikaninen and Kokko. 2009. Differential allocation and compensation: who deserves the silver spoon? Behavioral Ecology. 21:195-200.

[29]. Sakaluk SK, Avery RL and Weddle CB.2006. Cryptic sexual conflict in gift giving insects: chasing the chase-away. American Naturalist 167:94-104.

[30]. Simmons LW. 1986. Female choice in the field cricket Gryllus bimaculatus. Animal Behaviour 34:5 14631470 .

[31]. Simmons L. 1987. Female choice contributes to offspring fitness in the field cricket, Gryllus bimaculatus . Behavioral ecology and sociobiology. 21:5: 313-321.

[32]. Simmons LW, Beveridge M, Wedell N, and Tregenza T. 2006. Postcopulatory inbreeding avoidance by female crickets only revealed by molecular markers. Molecular Ecology. 15:12: 3817-3824.

[33]. Stanley DW, Miller J, and Tunaz H. 2009. Eicosanoid actions in insect immunity. Journal of innate immunity. 1:4: 282-290.

[34]. Stoffer B and Walker SE. 2011. The use of multimodal communication in mate-choice decisions by female house crickets, Acheta domesticus. Fullerton, CA: California State University, Fullerton.

[35]. Trivers, R. 1972. Parental investment and sexual selection. Chicago, IL. Aldine Publishing Co. 
[36]. Wagner WE Jr, Kelley RJ, Tucker KR, Harper CJ. 2001. Females receive a life-span benefit from male ejaculates in a field cricket. Evolution 55(5): 994-1001.

[37]. Weinheimer AD and Spraggins R L, 1969. The occurrence of two new prostaglandin derivatives (1 5-epiPGA2 and its acetate, methyl ester) in the gorgonian Plexaura homomalla. Tetrahedron Lett. 59: 5185-5188.

[38]. Wedell N, and Tregenza T.1999. Successful fathers sire successful sons. Evolution. 53:2:620-625.

[39]. Zeh JA, and Zeh DW. 2001. Reproductive mode and the genetic benefits of polyandry. Animal Behaviour. 61:6: 1051-1063.

\section{Appendices}

\section{Appendix A}

Figure S1: The pre-experimental mass (in grams) was recorded for all female crickets used for data. Here, the number of females was graphed as a function of mass in grams where the binning categories were made in 0.03 grams per interval. All the female crickets were $14 \mathrm{~d}$ post-adult ecolosion. The minimum mass recorded was $0.223 \mathrm{~g}$, the maximum mass recorded was $0.668 \mathrm{~g}$, and the average mass was recorded as $0.425+0.09 \mathrm{~g}$ These are cricket masses that were pooled from previous studies mentioned elsewhere. The groups were randomly assigned to different cohort studies mentioned elsewhere or to the mate-search behavior cohort.

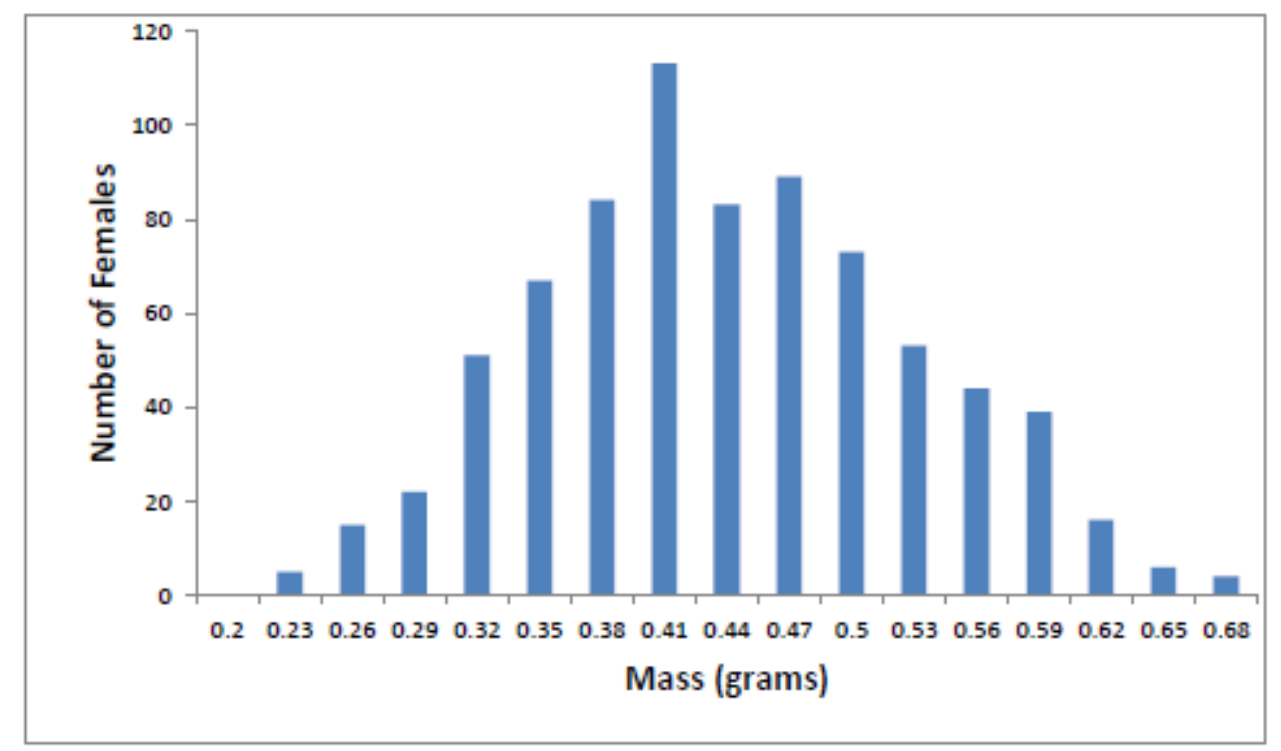

Figure S1. The pre-experimental mass for all females used

\section{Appendix B}

Table S1: Data table showing the demographics of individual cricket's used in Experiment three. Each row shows the individual cricket's mass in grams, the time taken to mount the speaker in seconds, and if the crickets received an acoustic stimulus or not. Crickets that took more than 10 min. to mount the speakers are noted as 600 .

Table S1. Data table of crickets for experiment three

\begin{tabular}{|llll|}
\hline Treatment & Mass (g) & Time (Sec.) & Acoustic Stimulus \\
\hline \hline $\begin{array}{l}\text { Untreated } \\
\text { Control }\end{array}$ & 0.417 & 600 & No \\
$\begin{array}{l}\text { Untreated } \\
\text { Control }\end{array}$ & 0.411 & 600 & No
\end{tabular}


DOI: 10.21522/TIJAR.2014.SE.19.01.Art005

ISSN: $2520-3088$

\begin{tabular}{|c|c|c|c|}
\hline $\begin{array}{l}\text { Untreated } \\
\text { Control }\end{array}$ & 0.508 & 600 & No \\
\hline $\begin{array}{l}\text { Untreated } \\
\text { Control }\end{array}$ & 0.331 & 600 & No \\
\hline $\begin{array}{l}\text { Untreated } \\
\text { Control }\end{array}$ & 0.517 & 600 & No \\
\hline $\begin{array}{l}\text { Untreated } \\
\text { Control }\end{array}$ & 0.450 & 600 & No \\
\hline $\begin{array}{l}\text { Untreated } \\
\text { Control }\end{array}$ & 0.293 & 121 & No \\
\hline $\begin{array}{l}\text { Untreated } \\
\text { Control }\end{array}$ & 0.474 & 600 & No \\
\hline $\begin{array}{l}\text { Untreated } \\
\text { Control }\end{array}$ & 0.409 & 553 & No \\
\hline $\begin{array}{l}\text { Untreated } \\
\text { Control }\end{array}$ & 0.406 & 600 & No \\
\hline $\begin{array}{l}\text { Untreated } \\
\text { Control }\end{array}$ & 0.405 & 600 & No \\
\hline $\begin{array}{l}\text { Untreated } \\
\text { Control }\end{array}$ & 0.420 & 492 & No \\
\hline $\begin{array}{l}\text { Untreated } \\
\text { Control }\end{array}$ & 0.337 & 600 & No \\
\hline $\begin{array}{l}\text { Untreated } \\
\text { Control }\end{array}$ & 0.490 & 600 & No \\
\hline $\begin{array}{l}\text { Untreated } \\
\text { Control }\end{array}$ & 0.363 & 600 & No \\
\hline $\begin{array}{l}\text { Untreated } \\
\text { Control }\end{array}$ & 0.444 & 600 & No \\
\hline $\begin{array}{l}\text { Untreated } \\
\text { Control }\end{array}$ & 0.482 & 600 & No \\
\hline $\begin{array}{l}\text { Untreated } \\
\text { Control }\end{array}$ & 0.396 & 600 & No \\
\hline $\begin{array}{l}\text { Untreated } \\
\text { Control }\end{array}$ & 0.388 & 600 & No \\
\hline $\begin{array}{l}\text { Untreated } \\
\text { Control }\end{array}$ & 0.280 & 600 & No \\
\hline $\begin{array}{l}\text { Untreated } \\
\text { Control }\end{array}$ & 0.241 & 600 & No \\
\hline $\begin{array}{l}\text { Untreated } \\
\text { Control }\end{array}$ & 0.433 & 600 & No \\
\hline $\begin{array}{l}\text { Untreated } \\
\text { Control }\end{array}$ & 0.346 & 600 & No \\
\hline $\begin{array}{l}\text { Untreated } \\
\text { Control }\end{array}$ & 0.305 & 600 & No \\
\hline $\begin{array}{l}\text { Untreated } \\
\text { Control }\end{array}$ & 0.309 & 600 & No \\
\hline
\end{tabular}


Texila International Journal of Academic Research Special Edition Apr 2019

\begin{tabular}{|llll} 
Sham Control & 0.389 & 600 & No \\
Sham Control & 0.322 & 600 & No \\
Sham Control & 0.359 & 600 & No \\
Sham Control & 0.392 & 600 & No \\
Sham Control & 0.448 & 600 & No \\
Sham Control & 0.393 & 600 & No \\
Sham Control & 0.362 & 65 & No \\
Sham Control & 0.415 & 600 & No \\
Sham Control & 0.307 & 600 & No \\
Sham Control & 0.505 & 600 & No \\
Sham Control & 0.324 & 600 & No \\
Sham Control & 0.344 & 600 & No \\
Sham Control & 0.452 & 600 & No \\
Sham Control & 0.440 & 600 & No \\
Sham Control & 0.576 & 600 & No
\end{tabular}


DOI: 10.21522/TIJAR.2014.SE.19.01.Art005

ISSN: $2520-3088$

\begin{tabular}{|c|c|c|}
\hline Sham Control & 0.286 & 600 \\
\hline Sham Control & 0.350 & 600 \\
\hline $\begin{array}{l}\text { Untreated } \\
\text { Control }\end{array}$ & 0.375 & 350 \\
\hline $\begin{array}{l}\text { Untreated } \\
\text { Control }\end{array}$ & 0.371 & 357 \\
\hline $\begin{array}{l}\text { Untreated } \\
\text { Control }\end{array}$ & 0.484 & 49 \\
\hline $\begin{array}{l}\text { Untreated } \\
\text { Control }\end{array}$ & 0.414 & 431 \\
\hline $\begin{array}{l}\text { Untreated } \\
\text { Control }\end{array}$ & 0.488 & 260 \\
\hline $\begin{array}{l}\text { Untreated } \\
\text { Control }\end{array}$ & 0.283 & 600 \\
\hline $\begin{array}{l}\text { Untreated } \\
\text { Control }\end{array}$ & 0.519 & 89 \\
\hline $\begin{array}{l}\text { Untreated } \\
\text { Control }\end{array}$ & 0.504 & 101 \\
\hline $\begin{array}{l}\text { Untreated } \\
\text { Control }\end{array}$ & 0.503 & 92 \\
\hline $\begin{array}{l}\text { Untreated } \\
\text { Control }\end{array}$ & 0.391 & 138 \\
\hline $\begin{array}{l}\text { Untreated } \\
\text { Control }\end{array}$ & 0.458 & 64 \\
\hline $\begin{array}{l}\text { Untreated } \\
\text { Control }\end{array}$ & 0.368 & 41 \\
\hline $\begin{array}{l}\text { Untreated } \\
\text { Control }\end{array}$ & 0.348 & 20 \\
\hline $\begin{array}{l}\text { Untreated } \\
\text { Control }\end{array}$ & 0.353 & 47 \\
\hline $\begin{array}{l}\text { Untreated } \\
\text { Control }\end{array}$ & 0.377 & 73 \\
\hline $\begin{array}{l}\text { Untreated } \\
\text { Control }\end{array}$ & 0.362 & 600 \\
\hline $\begin{array}{l}\text { Untreated } \\
\text { Control }\end{array}$ & 0.422 & 90 \\
\hline $\begin{array}{l}\text { Untreated } \\
\text { Control }\end{array}$ & 0.278 & 25 \\
\hline $\begin{array}{l}\text { Untreated } \\
\text { Control }\end{array}$ & 0.377 & 600 \\
\hline $\begin{array}{l}\text { Untreated } \\
\text { Control }\end{array}$ & 0.399 & 72 \\
\hline $\begin{array}{l}\text { Untreated } \\
\text { Control }\end{array}$ & 0.279 & 141 \\
\hline
\end{tabular}


Texila International Journal of Academic Research Special Edition Apr 2019

\begin{tabular}{|c|c|c|c|}
\hline $\begin{array}{l}\text { Untreated } \\
\text { Control }\end{array}$ & 0.343 & 600 & Yes \\
\hline $\begin{array}{l}\text { Untreated } \\
\text { Control }\end{array}$ & 0.383 & 20 & Yes \\
\hline $\begin{array}{l}\text { Untreated } \\
\text { Control }\end{array}$ & 0.385 & 60 & Yes \\
\hline Sham Control & 0.353 & 25 & Yes \\
\hline Sham Control & 0.646 & 222 & Yes \\
\hline Sham Control & 0.329 & 273 & Yes \\
\hline Sham Control & 0.382 & 175 & Yes \\
\hline Sham Control & 0.313 & 71 & Yes \\
\hline Sham Control & 0.550 & 26 & Yes \\
\hline Sham Control & 0.287 & 174 & Yes \\
\hline Sham Control & 0.275 & 10 & Yes \\
\hline Sham Control & 0.393 & 75 & Yes \\
\hline Sham Control & 0.412 & 21 & Yes \\
\hline Sham Control & 0.580 & 260 & Yes \\
\hline Sham Control & 0.402 & 202 & Yes \\
\hline Sham Control & 0.319 & 63 & Yes \\
\hline Sham Control & 0.440 & 77 & Yes \\
\hline Sham Control & 0.458 & 133 & Yes \\
\hline Sham Control & 0.425 & 276 & Yes \\
\hline Sham Control & 0.363 & 129 & Yes \\
\hline Sham Control & 0.401 & 49 & Yes \\
\hline Sham Control & 0.514 & 63 & Yes \\
\hline Sham Control & 0.409 & 600 & Yes \\
\hline
\end{tabular}


DOI: 10.21522/TIJAR.2014.SE.19.01.Art005

ISSN: $2520-3088$

\begin{tabular}{|c|c|c|c|}
\hline Sham Control & 0.478 & 213 & Yes \\
\hline Sham Control & 0.530 & 54 & Yes \\
\hline Sham Control & 0.600 & 106 & Yes \\
\hline Sham Control & 0.426 & 187 & Yes \\
\hline Sham Control & 0.559 & 56 & Yes \\
\hline $100 \mu \mathrm{g}$ & 0.510 & 23 & Yes \\
\hline $100 \mu \mathrm{g}$ & 0.488 & 217 & Yes \\
\hline $100 \mu \mathrm{g}$ & 0.423 & 66 & Yes \\
\hline $100 \mu \mathrm{g}$ & 0.477 & 34 & Yes \\
\hline $100 \mu \mathrm{g}$ & 0.428 & 37 & Yes \\
\hline $100 \mu \mathrm{g}$ & 0.460 & 17 & Yes \\
\hline $100 \mu \mathrm{g}$ & 0.436 & 54 & Yes \\
\hline $100 \mu \mathrm{g}$ & 0.380 & 19 & Yes \\
\hline $100 \mu \mathrm{g}$ & 0.535 & 105 & Yes \\
\hline $100 \mu \mathrm{g}$ & 0.495 & 175 & Yes \\
\hline $100 \mu \mathrm{g}$ & 0.278 & 302 & Yes \\
\hline $100 \mu \mathrm{g}$ & 0.297 & 56 & Yes \\
\hline $100 \mu \mathrm{g}$ & 0.332 & 171 & Yes \\
\hline $100 \mu \mathrm{g}$ & 0.249 & 76 & Yes \\
\hline $100 \mu \mathrm{g}$ & 0.336 & 131 & Yes \\
\hline $100 \mu \mathrm{g}$ & 0.226 & 174 & Yes \\
\hline $100 \mu \mathrm{g}$ & 0.431 & 94 & Yes \\
\hline $100 \mu \mathrm{g}$ & 0.501 & 44 & Yes \\
\hline $100 \mu \mathrm{g}$ & 0.624 & 600 & Yes \\
\hline $100 \mu \mathrm{g}$ & 0.537 & 60 & Yes \\
\hline $100 \mu \mathrm{g}$ & 0.607 & 600 & Yes \\
\hline $100 \mu \mathrm{g}$ & 0.316 & 62 & Yes \\
\hline $100 \mu \mathrm{g}$ & 0.548 & 238 & Yes \\
\hline $10 \mu \mathrm{g}$ & 0.620 & 595 & Yes \\
\hline $10 \mu \mathrm{g}$ & 0.520 & 367 & Yes \\
\hline $10 \mu \mathrm{g}$ & 0.318 & 169 & Yes \\
\hline $10 \mu \mathrm{g}$ & 0.356 & 600 & Yes \\
\hline $10 \mu \mathrm{g}$ & 0.523 & 82 & Yes \\
\hline $10 \mu \mathrm{g}$ & 0.467 & 24 & Yes \\
\hline $10 \mu \mathrm{g}$ & 0.540 & 168 & Yes \\
\hline $10 \mu \mathrm{g}$ & 0.300 & 156 & Yes \\
\hline $10 \mu \mathrm{g}$ & 0.501 & 192 & Yes \\
\hline $10 \mu \mathrm{g}$ & 0.422 & 71 & Yes \\
\hline $10 \mu \mathrm{g}$ & 0.599 & 63 & Yes \\
\hline $10 \mu \mathrm{g}$ & 0.372 & 600 & Yes \\
\hline $10 \mu \mathrm{g}$ & 0.451 & 41 & Yes \\
\hline
\end{tabular}


Texila International Journal of Academic Research Special Edition Apr 2019

\begin{tabular}{|llll|}
$10 \mu \mathrm{g}$ & 0.292 & 214 & Yes \\
$10 \mu \mathrm{g}$ & 0.513 & 80 & Yes \\
$10 \mu \mathrm{g}$ & 0.531 & 72 & Yes \\
$10 \mu \mathrm{g}$ & 0.522 & 61 & Yes \\
$10 \mu \mathrm{g}$ & 0.486 & 116 & Yes \\
$10 \mu \mathrm{g}$ & 0.496 & 220 & Yes \\
$10 \mu \mathrm{g}$ & 0.311 & 600 & Yes \\
$10 \mu \mathrm{g}$ & 0.463 & 17 & Yes \\
$1 \mu \mathrm{g}$ & 0.374 & 281 & Yes \\
$1 \mu \mathrm{g}$ & 0.485 & 156 & Yes \\
$1 \mu \mathrm{g}$ & 0.457 & 320 & Yes \\
$1 \mu \mathrm{g}$ & 0.322 & 25 & Yes \\
$1 \mu \mathrm{g}$ & 0.320 & 230 & Yes \\
$1 \mu \mathrm{g}$ & 0.398 & 26 & Yes \\
$1 \mu \mathrm{g}$ & 0.393 & 270 & Yes \\
$1 \mu \mathrm{g}$ & 0.455 & 189 & Yes \\
$1 \mu \mathrm{g}$ & 0.429 & 114 & Yes \\
$1 \mu \mathrm{g}$ & 0.358 & 24 & Yes \\
$1 \mu \mathrm{g}$ & 0.466 & 20 & Yes \\
$1 \mu \mathrm{g}$ & 0.380 & 164 & Yes \\
$1 \mu \mathrm{g}$ & 0.601 & 46 & Yes \\
$1 \mu \mathrm{g}$ & 0.544 & 315 & Yes \\
\hline
\end{tabular}

